\title{
EFEKTIVITAS PERATURAN PRESIDEN NOMOR 44 TAHUN 2016 TERHADAP KESEMPATAN KERJA PRODUKTIF BAGI TENAGA KERJA DALAM KEGIATAN PENANAMAN MODAL PADA SEKTOR PERKEBUNAN DI SUMATERA BARAT
}

\author{
Wira Okta Viana ${ }^{3}$, Mashudi' ${ }^{2}$ Iyah Faniyah ${ }^{3}$ \\ Program Studi Pascasarjana Ilmu Hukum \\ Universitas Ekasakti Padang
}

\begin{abstract}
Presidential Regulation number 44 of 2016 regulates the list of closed business fields with requirements in the field of investment. The issuance of Presidential Regulation number 44 of 2016 is expected to be implemented effectively and efficiently to the opening of productive employment opportunities for workers in investment activities, especially in the plantation sector in West Sumatera.The issues raised in writing this thesis are: First how the effectiveness of Presidential Regulation number 44 of 2016 on productive employments opportunities for labor in investment activities in West Sumatera. Second the factors that hamper the effectviness of Presidential Regulation number 44 of 2016 on productive employment opportunities for labor in plantation investment activities in West Sumatera. Third how is policy of West Sumatera provincial government related to the effectiveness of presidential regulation number 44 year 2016 in productive employment opportunity for manpower in investment activity in West Sumatera.The research method used in the writing of this thesis is the normative juridical approach supported by empirical juridical approach through interview techniques and date collection techniques by the author at the Office of One Stop Service Integrated Servive Center (DPMPTSP) of West Sumatera Province and the Office of Manpower ang Tranmigration of Sumatera Province West. Based on the results of research and analysis, it can be concluded as follows: First effectiveness Presidential Regulation number 44 of 2016 on productive employment opportunities for labor in plantation investment activities in West Sumatera has been running effectively but still not maximal because it still encountered some obstacles and weaknesses in this Presidential Regulation and its implementation. Second The internal factors included the absence of provisions on the maximum dan minimum limits of plantation land use, business scale, and so forth. External factors included limited land fpr plantations, land with traditional customary community land, low labor human resources, and investment licensing issues that are perceived as inefficient. Third West Sumatera provincial governments have issued regulations stipulated in the Regional Regulation and Governor Regulation which is guided by the provisions of Presidential Regulation number 44 of 2016 and other legislation related to the increase of employment and investment activities, especially the plantation sector in West Sumatera. One of them is Regional Regulation of West Sumatera Province number 2 of 2014 concerning Investment and Regulation of Gubernur of West Sumatera number 70 year 2013 concerning General Plan of Capital Investment of West Sumatera.
\end{abstract}

Kata Kunci : Kesempatan Kerja, Tenaga Kerja, dan Penanamaan Modal.

\section{PENDAHULUAN}

Cita-cita mewujudkan Indonesia sebagai negara kesejahteraan (welfare state) telah diamanatkan dengan jelas dalam falsafah negara yaitu Pancasila dan UUD 1945. Campur tangan pemerintah dalam aspek regulasi dimaksudkan untuk menciptakan kesejahteraan masyarakat secara 
merata supaya free flight liberalism dapat terhindar. Pasal 33 Ayat (4) UUD 1945 yang merupakan landasan utama perekonomian nasional menyatakan bahwa perekonomian nasional diselenggarakan berdasarkan atas demokrasi ekonomi dengan prinsip kebersamaan, efisiensi berkeadilan, berkelanjutam, berwawasan lingkungan, kemandirian, serta dengan menjaga keseimbangan kemajuan dan kesatuan ekonomi nasional.

Pada tahun 1966, pemerintah Indonesia mengadakan pendekatan baru dalam kebijkasanaan ekonomi, antara lain mengundang kembali masuknya modal asing. Undang-undang yang baru tentang penanaman modal asing diundangkan pada tahun 1967, yaitu UU No. 1 Tahun 1967, Lembaran Negara Republik Indonesia Tahun 1967 Nomor 1, Tambahan Lembaran Negara Republik Indonesia Nomor 2818. Dalam kaitannya dengan penanaman modal, setahun kemudian pemerintah mengeluarkan UU No. 6 Tahun 1968 tentang Penanaman Modal Dalam Negeri, Lembaran Negara Republik Indonesia Tahun 1968 Nomor 33, Tambahan Lembaran Negara Republik Indonesia Nomor $2853 .{ }^{1}$

\footnotetext{
${ }^{1}$ Erman Rajagukguk, Indonesianisasi Saham, Rineka Cipta, Jakarta. 1985. hlm 2.

2 G. Kartasaputra, Manajemen Penanaman Modal Asing, Bina Aksara, Jakarta, 1985. hlm. 4.

${ }^{3}$ News Sindo, "Wirausaha RI masih jauh tertinggal", artikel diakses pada 14 November 2016 dari
}

Pada Maret 2007, Dewan Perwakilan Rakyat telah mensahkan berlakunya UndangUndang Penanaman Modal yang baru untuk menggantikan undang-undang penanaman modal yang selama ini berlaku baik dalam UUPMDN maupun UUPMA, yaitu UU Nomor 25 Tahun 2007 tentang Penanaman Modal (UUPM) tanggal 26 April Tahun 2007, Lembaran Negara Republik Indonesia tahun 2007 Nomor 67, Tambahan Lembaran Negara Republik Indonesia Nomor $4724{ }^{2}$

Menurut hasil penelitian atau riset yang dilakukan oleh berita harian sindo menyatakan bahwa, suatu negara akan makmur jika warga negaranya minimal memiliki $2 \%$ pengusaha atau investor, sedangkan Indonesia hanya memiliki 0,24\% pengusaha atau investor dari total warga negaranya. Indonesia kalah sangat jauh jika dibandingkan dengan Amerika yang memiliki $11 \%$ dari warga negaranya yang menjadi pengusaha atau investor. ${ }^{3}$

Selain PDB dan penerimaan ekspor, sub sektor perkebunan juga memberikan lapangan pekerjaan yang cukup besar. Potensi sektor perkebunan masih sangat menjanjikan. Sumbangan sektor ini terhadap PDB nasional Tahun 2016 mencapai Rp.429 triliun dan dari sawit sebesar Rp.260 triliun. ${ }^{4}$ Merujuk data

http://www.sindonews.com/read/2012/04/13/450/6108 31/wirausaha-ri-masih-jauh-tertinggal.

${ }^{4}$ Industri perkebunan jadi penopang ekonomi nasional, artikel diakses pada 10-1-2018 dari $\mathrm{m}$. tribunnews. com > bisnis > industri / 11/12/2017/ industri-perkebunanjadi-penopang-ekonomi-nasional. 
Statistik Perkebunan Indonesia tahun 2016 dari sisi pemasukan, perkebunan kelapa sawit juga memberikan lapangan pekerjaan bagi masyarakat Indonesia, sehingga dari 250 juta warga Indonesia ada sekitar 5,7 juta jiwa yang bekerja di perkebunan sawit, dengan 2,2 juta orang diantaranya adalah petani rakyat skala kecil. Saat ini luas perkebunan kelapa sawit diperkirakan mencapai 11,6 juta hectare, dimana lebih dari 41 persen merupakan kebun rakyat. ${ }^{5}$ Perkembangan sub sektor perkebunan Indonesia tidak terlepas dari kebijakan, program dan langkah pemerintah. Disamping itu, tidak terlepas dari upaya para pemangku kepentingan perkebunan lainnya, diantaranya pelaku usaha perkebunan, baik perusahaan negara, perusahaan swasta yang berasal dari penanaman modal asing, dan pekebun.

Badan Koordinasi Penanaman Modal (BKPM) merilis data realisasi investasi Penanaman Modal Dalam Negeri (PMDN) dan Penanaman Modal Asing (PMA) triwulan pertama (periode Januari-Maret) tahun 2017 mencapai angka RP.165 triliun, meningkat $13,2 \%$ dari periode yang sama tahun 2016 sebesar Rp.146,5\% triliun. Realisasi investasi tersebut menyerap 194.134 ribu orang yang terdiri proyek PMDN sebanyak 67.807 orang dan proyek PMA sebanyak 126.327 orang. Angka capaian tambahan tenaga kerja ini positif bagi upaya pemerintah untuk

\footnotetext{
${ }^{5}$ Industri sawit serap tenaga kerja 5,7 juta orang di 2016, artikel diakses pada 10-1-2018 dari https://m. suara. com > bisnis > 2017/02/04/ industri-sawit-serap-tenaga-kerja5,7 juta-orang-di-2016.
}

mendorong terjadinya penciptaan lapangan kerja bagi masyarakat Indonesia. ${ }^{6}$

Dalam rangka mengatasi masalah ketenagakerjaan, pemerintah harus menempuh kebijaksanaan dan langkahlangkah yang bersifat menyeluruh. Sasaran yang ingin dicapai adalah perluasan kesempatan kerja produktif, pemerataan kegiatan dan pemerataan hasil pembangunan seperti yang dijelaskan dalam Pasal 2 Undang-Undang Nomor 13 Tahun 2003 tentang Ketenagakerjaan "Pembangunan ketenagakerjaan berlandaskan Pancasila dan Undang-Undang Dasar Negara Republik Indonesia Tahun 1945".

Undang-Undang Perkebunan yang baru yaitu Undang-Undang Nomor 39 Tahun 2014 memuat beberapa pengaturan baru yaitu: Penetapan batas luas maksimum dan minimum lahan usaha perkebunan; Perbenihan; Budi daya tanaman perkebunan; Tindakan yang dilarang; Kewajiban memfasilitasi pembangunan kebun masyarakat; Kewajiban bagi unit pengolahan hasil perkebunan tertentu yang berbahan baku impor; Sistem data dan informasi; Pembatasan penanaman modal asing; Pembinaan teknis dan evaluasi atas

\footnotetext{
${ }^{6}$ Laporan Kinerja BKPM 2016, artikel diakses pada 101-2018 dari www. BKPM. go.id > ppid, file_upload/ laporan-kinerja-BKPM-2016
} 
kinerja perusahaan perkebunan; Peran serta masyarakat; dan ketentuan pidana.

Setelah dikeluarkannya Peraturan Presiden Nomor 44 Tahun 2016 tentang Daftar Bidang Usaha yang Tertutup dan Bidang Usaha yang Terbuka dengan Persyaratan di Bidang Penanaman Modal, telah terjadi pembatasan investasi asing atau penanaman modal asing pada satu usaha perkebunan di Indonesia pada umumnya dan Provinsi Sumatera Barat khususnya.

Berdasarkan uraian dari latar belakang diatas, maka permasalahan yang dapat penulis bahas adalah untuk mengetahui dan menganalisis kebijakan pemerintah propinsi Sumatera Barat terhadap efektivitas Peraturan Presiden Nomor 44 Tahun 2016 terhadap kesempatan kerja produktif bagi tenaga kerja dalam kegiatan penanaman modal sektor perkebunan di Sumatera Barat.

\section{METODE PENELITIAN}

Untuk menjawab permasalahan seperti yang telah diuraikan diatas, maka dalam melaksanakan penelitian yang berfungsi sebagai acuan, sehingga hasil dari penelitian dapat menemui sasaran dan dapat dipertanggung jawabkan.

Metode pendekatan yang digunakan dalam penelitian ini adalah pendekatan yuridis normatif yang didukung oleh pendekatan yuridis empiris. Pendekatan yuridis normatif digunakan untuk menguraikan bahan-bahan kepustakaan berupa peraturan perundang-undangan, bukubuku dan hasil penelitian yang terkait dengan masalah yang diteliti. Sedangkan pendekatan yuridis empiris digunakan untuk mengetahui bekerjanya hukum dalam masyarakat mengenai pengaruh pemanfaatan penanaman modal asing di sektor perkebunan terhadap kesempatan kerja bagi usia kerja produktif di daerah Provinsi Sumatera Barat.

Data dianalisis secara data sekunder dan data primer dalam penelitian ini yang diperoleh dengan cara studi kepustakaan dan wawancara kemudian dianalisis secara kualitatif dan disajikan dalam bentuk deskriptif.

\section{HASIL PENELITIAN}

Hasil penelitian tentang kesempatan kerja produktif bagi tenaga kerja dalam kegiatan penanaman modal sektor perkebunan di Sumatera Barat.

Data Perusahaan Penanaman Modal Dalam Negeri (PMDN) Menurut Lokasi di Provinsi Sumatera Barat sebagai berikut :

\section{Tabel 1}

Jumlah Perusahaan Penanamaan Modal Dalam Negeri (PMDN)

di Kabupaten/Kota Provinsi Sumatera Barat 


\begin{tabular}{|c|l|c|c|}
\hline No & \multicolumn{1}{|c|}{ Kabupaten/Kota } & $\begin{array}{c}\text { Jumlah } \\
\text { Perusahaan }\end{array}$ & $\begin{array}{c}\text { Persaentase dari } \\
\text { Total Perusahaan }\end{array}$ \\
\hline 1 & Kota Padang & 75 & $18,61 \%$ \\
\hline 2 & Kabupaten Lima Puluh Kota & 72 & $17,87 \%$ \\
\hline 3 & Kabupate Sijunjung & 53 & $13,15 \%$ \\
\hline 4 & Kabupaten Agam & 29 & $7,20 \%$ \\
\hline 5 & Kabupaten Pesisir Selatan & 27 & $6,70 \%$ \\
\hline 6 & Kabupaten Dharmasraya & 21 & $5,21 \%$ \\
\hline 7 & Kabupaten Padang Pariaman & 19 & $4,71 \%$ \\
\hline 8 & Kabupaten Solok Selatan & 19 & $4,71 \%$ \\
\hline 9 & Kabupaten Pasaman Barat & 18 & $4,47 \%$ \\
\hline 10 & Kabupaten Kepulauan Mentawai & 15 & $3,72 \%$ \\
\hline 11 & Kabupaten Tanah Datar & 15 & $3,72 \%$ \\
\hline 12 & Kota Bukittinggi & 14 & $3,47 \%$ \\
\hline 13 & Kabupaten Solok & 10 & $2,48 \%$ \\
\hline 14 & Kabupaten Pasaman & 7 & $1,74 \%$ \\
\hline 15 & Kota Pariaman & 3 & $0,74 \%$ \\
\hline 16 & Kota Padang Panjang & 2 & $0,50 \%$ \\
\hline 17 & Kota Sawahlunto & 2 & $0,50 \%$ \\
\hline 18 & Kota Payahkumbuah & 1 & $0,25 \%$ \\
\hline 19 & Kota Solok & 1 & $0,25 \%$ \\
\hline \multicolumn{2}{|c|}{ Jumlah } & $\mathbf{4 0 3}$ & $\mathbf{1 0 0} \%$ \\
\hline
\end{tabular}

Sumber:Bidang Pengendalian Pelaksanaan Penanaman Modal \& Sistem Informasi Penanaman Modal - Dinas Penanaman Modal \& PTSP Provinsi Sumatera Barat, Tahun 2017

Berdasarkan data yang dihimpun oleh

Dinas Penanaman Modal dan Pelayanan Terpadu Satu Pintu Provinsi Sumatera Barat sejak tahun 1969 hingga sekarang, Kota Padang dan Kabupaten Lima Puluh Kota merupakan daerah yang paling diminati oleh investor PMDN dalam menanamkan modalnya. Di Kota Padang sendiri terdapat 75 perusahaan, diikuti oleh Kabupaten Lima Puluh Kota dengan 72 perusahaan. Daerah berikutnya yang diminati oleh investor PMDN adalah Kabupaten Sijunjung (53 perusahaan), Kabupaten Agam perusahaan), Kabupaten Pesisir Selatan (27 perusahaan), dan Kabupaten Dharmasraya (21 perusahaan).

Berdasarkan data yang penulis peroleh dari Dinas Penanaman Modal \& Pelayanan Terpadu Satu Pintu Provinsi Sumatera Barat terkait dengan perusahaan PMDN yang melakukan realisasi proyek khusus bidang usaha perkebunan di Sumatera
Barat dari bulan Januari sampai dengan Desember tahun 2016, untuk lokasi perkebunan ada pada 8 Kabupaten yaitu Solok Selatan, Lima Puluh Kota, Pasaman Barat, Agam, Sijunjung. Untuk Kabupaten Lima Puluh Kota ada 3 titik lokasi dan Kabupaten Sijunjung ada 2 titik lokasi perkebunan, dengan jumlah realisasi seperti yang tertera pada tabel diatas. Terkait jumlah tenaga kerja hanya ada 2 Kabupaten yang menyerap tenaga kerja (tenaga kerja Indonesia) yaitu di Kabupaten Solok Selatan (134 orang) dan Kabupaten Agam (66 orang) dalam jumlah yang sedikit.

Untuk jumlah tenaga kerja berdasarkan Kabupaten dan skala perusahaan di Sumatera Barat tahun 2017, bersumber dari buku Data Ketenagakerjaan dan Transmigrasi Tahun 2017 dapat dilihat pada tabel dibawah ini:

Tabel 2

Jumlah Tenaga Kerja Berdasarkan Kabupaten dan Skala Perusahaan di Sumatera Barat Tahun 2017

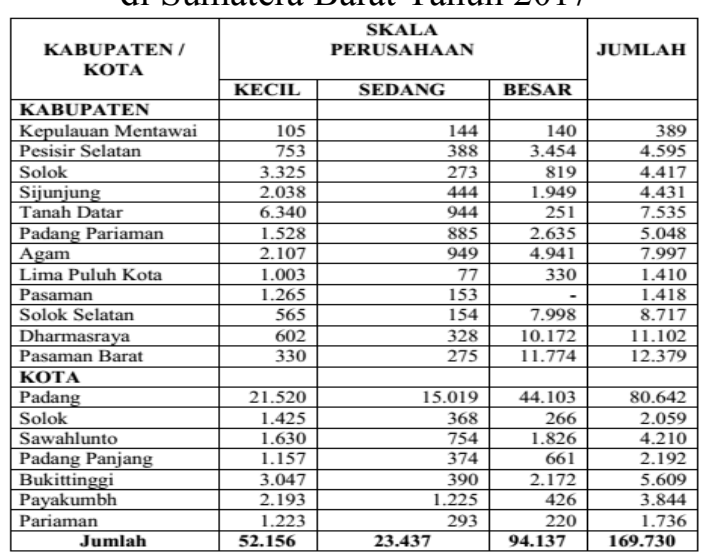

Secara keseluruhan jumlah tenaga

kerja di Sumatera Barat untuk tahun 2017 sebanyak 169.730 orang, yang dihimpun dari 
semua skala perusahaan baik skala kecil, sedang dan skala besar. Terlihat sekali Pemerintah Daerah khususnya Dinas yang terkait dalam melaksanakan kewenangannya tidak setengah-setengah dalam memusatkan perhatian kepada masyarakat dalam memberikan dedikasi yang terbaik untuk masyarakat agar mampu memperoleh pekerjaan dan menjadi tenaga kerja yang berpotensi. Melalui berbagai program pemerintah yang dilaksanakan dalam hal ini khususnya Dinas Tenaga Kerja dan Transmigrasi Sumatera Barat memberdayakan masyarakatnya agar menjadi tenaga kerja yang memiliki kualifikasi baik salah satunya dengan melaksanakan kegiatan Lembaga Pelatihan Kerja (LPK) sehingga memberikan manfaat kepada masyarakat dalam meningkatkan kemampuan menjadi tenaga kerja profesional dan semakin meningkat penyerapan tenaga kerja di Sumatera Barat.

Peraturan Presiden Nomor 44 Tahun 2016 mengatur tentang Daftar Bidang Usaha yang Tertutup dan Daftar Bidang Usaha yang Terbuka dengan Persyaratan di Bidang Penanaman Modal.Pasal 1 dalam Perpres ini menjelaskan pengertian tentang Bidang Usaha, Bidang Usaha yang Terbuka, Bidang Usaha yang Tertutup, Bidang Usaha yang Terbuka dengan Persyaratan, Penanaman Modal, Penanam Modal, Kemitraan, Usaha Mikro Kecil dan Menengah, dan Koperasi.
Menurut Kamus Besar Bahasa Indonesia (KBBI) arti dari kata penerapan itu adalah proses, cara, perbuatan menerapkan. Sedangkan menurut beberapa ahli berpendapat bahwa penerapan merupakan suatu perbuatan mempraktekkan suatu teori, metode, dan hal lain untuk mencapai tujuan tertentu dan untuk suatu kepentingan yang di inginkan oleh suatu kelompok atau golongan yang telah terencana dan tersusun sebelumnya.

Demikian hal nya dalam upaya untuk meningkatkan penanaman modal di Indonesia dan persiapan menghadapi ASEAN Economic Community (AEC), Pemerintah Indonesia memperbaiki ketentuan daftar bidang usaha yang tertutup dan terbuka dengan persyaratan di bidang penanaman modal (Daftar Negatif Investasi/DNI).

Perbaikan ini tertuang dalam Peraturan Presiden Nomor 44 Tahun 2016 tentang Daftar Bidang Usaha yang Tertutup dan Bidang Usaha yang Terbuka dengan Persyaratan di Bidang Penanaman Modal, yang ditandatangani Presiden Joko Widodo pada tanggal 12 Mei 2016. Peraturan baru menggantikan peraturan lama, yakni Peraturan Presiden Nomor 39 Tahun 2014.

Peranan Peraturan Presiden Nomor 44 Tahun 2016 tentang Daftar Bidang Usaha yang Tertutup dan Bidang Usaha yang Terbuka dengan Persyaratan di Bidang Penanamaan Modal, semakin memperkuat aturan hukum yang telah tertuang baik dalam 
bentuk Peraturan Daerah maupun Peraturan Gubernur Sumatera Barat, yang mana segala ketentuannya mengatur tentang kegiatan penanaman modal di Sumatera Barat agar kegiatan penanaman modal di Sumatera Barat semakin meningkat. Dengan adanya laju kegiatan penanaman modal di Sumatera Barat tentunya akan memberikan kesempatan bekerja bagi masyarakat, terciptanya lapangan usaha sehingga meminimalisisr angka pengangguran di Sumatera Barat, tentunya untuk kesejahteraan dan kemakmuran hidup masyarakat di Sumatera Barat khususnya.

\section{PEMBAHASAN}

Efektivitas Peraturan Presiden Nomor 44 Tahun 2016 terhadap Kesempatan Kerja Produktif bagi Tenaga Kerja dalam Kegiatan Penanaman Modal Sektor Perkebunan di Sumatera Barat

Berbicara mengenai efektivitas suatu peraturan perundang-undangan berkaitan dengan efektivitas hukum, yaitu tidak terlepas dari makna bagaimana berlakunya suatu aturan hukum di dalam suatu negara, salah satu tujuannya adalah memberikan kepastian hukum terhadap masyarakat, agar masyarakat dapat mengetahui dan memahami bagaimana aturan hukum di dalam suatu negara berlaku dan bekerja.

Menurut Soerjono Soekanto, ada 5 (lima) faktor yang mempengaruhi penegakan hukum, dalam hal ini yang terkait dengan Efektivitas Peraturan Presiden Nomor 44
Tahun 2016 terhadap kesempatan kerja bagi tenaga kerja produktif dalam kegiatan penanaman modal di Sumatera Barat, yaitu: 1) Faktor hukumnya sendiri, 2) Faktor penegak hokum, 3) Faktor sarana dan fasilitas pendukung, 4) Faktor masyarakat, dan 5) Faktor kebudayaan.

Dalam teori hukum Donald Black mengenai berlakunya hukum dalam kehidupan masyarakat, analisis hukum yang diterapkan tidak hanya meliputi substansial atau prosedural tetapi juga sosiologis yang tidak melibatkan penilaian politik hukum sebagai prilaku karena merupakan pendekatan murni sosiologi hukum yang dapat menduga dan menjelaskan prilaku hukum (behaviour of law).

Peraturan Presiden Nomor 44 Tahun 2016 tentang Daftar Bidang Usaha yang Tertutup dan Bidang Usaha yang Terbuka dengan Persyaratan di Bidang Penanaman Modal dibuat berdasarkan pedoman kepada ketentuan dalam Undang-Undang Nomor 25 Tahun 2007 tentang Penanaman Modal. Keterkaitannya terletak pada bidang-bidang usaha yang dipersyaratkan di bidang penanaman modal. Selanjutnya kegiatan penanaman modal bergerak diberbagai sektor usaha seperti pertambangan, perindustrian, ketenagalistrikan, perkebunan dan lain sebagainya yang jenis bidang usaha tersebut merupakan bidang usaha yang terbuka dengan persyaratan yang terdapat dalam ketentuan Perpres 44 Tahun 2016 tersebut. Salah 
satunya kegiatan atau bidang usaha yang terbuka dengan persyaratan adalah bidang usaha yang bergerak disektor perkebunan.

Selain itu, dari berbagai sektor kegiatan perekonomian nasional yang diatur dalam Peraturan Presiden Nomor 44 Tahun 2016 tersebut, juga ada yang dicadangkan untuk kemitraan atau Usaha Mikro, Kecil dan Menengah serta Koperasi seperti yang diatur dalam ketentuan Undang-Undang Nomor 25 Tahun 2007 tentang Penanaman Modal serta Peraturan Presiden Nomor 44 Tahun 2016 tentang Daftar Bidang Usaha yang Tertutup dan Bidang Usaha yang Terbuka dengan Persyaratan di Bidang Penanaman Modal, yang salah satunya pada sektor pertanian atau perkebunan. Adapun tujuan nya adalah untuk mensejahterakan kehidupan masyarakat melalui kemitraan atau UMKMK dari kegiatan sektor perkebunan sehingga dapat membuka kesempatan kerja dan menyerap tenaga kerja yang produktif dalam jumlah yang besar dan meminimalisisr angka penganguran di Sumatera Barat.

Kendala-Kendala yang Menjadi Penghambat dalam Efektivitas Peraturan Presiden Nomor 44 Tahun 2016 terhadap Kesempatan Kerja Produktif bagi Tenaga Kerja dalam Kegiatan Penanaman Modal Sektor Perkebunan di Sumatera Barat
Dalam penerapan suatu aturan akan selalu ada kendala-kendala atau hambatan yang akan menjadi penyebab sehingga tidak efektifnya suatu aturan tersebut untuk dilaksanakan. Terkait dengan Peraturan Presiden Nomor 44 Tahun 2016 yang mengatur tentang Daftar Bidang Usaha yang Tertutup dan Bidang Usaha yang Terbuka dengan Persyaratan di Bidang Penanaman Modal, berdasarkan uraian yang telah dijelaskan sebelumnya bahwasanya aturan Perpres 44 Tahun 2016 mengacu kepada kegiatan penanaman modal di sektor perkebunan dan memberikan kesempatan kerja produktif bagi tenaga kerja khususnya di Sumatera Barat. Ketiga variabel tersebut yaitu penanaman modal, sektor perkebunan dan kesempatan kerja produktif bagi tenaga kerja, saling berkaitan antara satu dengan yang lainnya. Seperti pemilik modal atau investor menjadikan suatu kawasan untuk kegiatan perkebunan berkapasitas besar, yang pastinya akan menyerap tenaga kerja dalam nominal yang besar juga.

Merujuk kepada Peraturan Presiden Nomor 44 Tahun 2016, ada beberapa hambatan atau kendala-kendala, baik dari kegiatan penanaman modal, perkebunan dan masalah ketenagakerjaan.

Kendala internal dari Peraturan Presiden Nomor 44 Tahun 2016 tentang Daftar Bidang Usaha yang Tertutup dan Bidang Usaha yang Terbuka dengan Persyaratan di Bidang Penanamaan Modal 
yaitu tidak dijelaskannya ketentuan mengenai batasan maksimum dan minimum dari penggunaan lahan atau lokasi dalam kegiatan penanaman modal, jenis tanaman perkebunan, skala usaha dan kondisi wilayah tertentu dalam Peraturan Presiden ini dan UndangUndang Perkebunan, sehingga tidak ada pedoman ketentuan yang jelas bagi investor dalam menentukan batas maksimal dan minimum dari lokasi perkebunan. Selain itu dalam Peraturan Presiden Nomor 44 tahun 2016 terkait dengan pengaturan permodalan dalam kegiatan penanamana modal hanya dijelaskan untuk penanaman modal asing, sedangkan untuk penanaman modal dalam negeri tidak dijelaskan.

Selanjutnya kendala eksternal Untuk kegiatan penanaman modal yaitu, berdasarkan informasi dari wawancara penulis dapatkan pada saat melakukan penelitian atau survey di Kantor Dinas Penanaman Modal dan Pelayanan Terpadu Satu Pintu, ada beberapa kendala yang masih menjadi keluhan bagi para investor. Seperti masalah perizinan yang dirasakan masih belum efektif, keterbatasan lahan untuk kegiatan perkebunan. Berdasarkan hasil wawancara penulis bersama bapak Bimbi Irawan selaku Kepala Sesi Pengolahan Data dan Sistem Informasi Penanaman Modal pada kantor DPMPTSP Provinsi Sumatera Barat ${ }^{7}$, menyebutkan saat ini kegiatan penanaman

\footnotetext{
${ }^{7}$ Hasil wawancara penulis bersama bapak Bimbi Irawan selaku Kepala Sesi Pengolahan Data dan Sistem
}

modal di sektor perkebunan sudah mulai statis atau berkurang bahkan akan dihentikan karena terkait dengan keterbatasan lahan, tidak ada lagi lahan yang bisa dijadikan untuk kawasan perkebunan (kebun kelapa sawit), dulu ada moratorium di sektor perkebunan disebabkan lahan yang ada di Sumatera Barat sudah terbatas karena sudah ada berbagai macam kegiatan perkebunan yang dilakukan, selain itu masalah tanah ulayat juga menjadi kendala yang dikeluhkan para investor. Pada saat pihak perusahaan perkebunan sedang dalam tahap pengerjaan untuk kegiatan perkebunan, masyarakat datang mengatakan keberatan untuk kegiatan perkebunan dengan alasan tanah perkebunan adalah milik mereka (tanah ulayat).

Untuk kegiatan perkebunan, kendala yang ditemui yaitu masalah izin pendirian pabrik pengolahan kelapa sawit, adanya gangguan dari masyarakat sekitar seperti demo yang mereka lakukan terhadap pihak perusahaan perkebunan karena tidak setuju untuk pembangunan pabrik pengolahan kelapa sawit dengan berbagai alasan yang mereka sampaikan, meski tujuan pihak perusahaan perkebunan adalah untuk mempermudah kinerja pengolahan kelapa sawit dan meminimalisir anggaran perusahaan selain itu juga untuk menyerap tenaga kerja agar masyarakat sekitar dapat memiliki pekerjaan. Padahal izin gangguan Provinsi Sumatera Barat, pada tanggal 17 April 2018 
sudah diurus namun masih terjadi gangguangangguan dari masyarakat sekitar.

Dalam hal ketenagakerjaan juga ditemukan beberapa kendala sehingga menghambat dalam penyerapan tenaga kerja di Sumatera Barat, kondisi ketenagakerjaan di Sumatera Barat menghadapi banyak tantangan selain turunnya penyerapan tenaga kerja dan naiknya tingkat pengangguran. Penyerapan tenaga kerja di sektor informal berjumlah 64,39\% (tahun 2017) sedangkan tahun 2016 berjumlah 61,80\%, yang diakibatkan investasi relatif masih belum banyak. Selain itu, produktivitas tenaga kerja (kualitas dan keterampilan) yang masih rendah bahkan tidak sesuai dengan kualifikasi yang dibutuhkan perusahaan.

Kebijakan Pemerintah Provinsi Sumatera Barat terkait Efektivitas Peraturan Presiden Nomor 44 Tahun 2016 terhadap Kesempatan Kerja Produktif bagi Tenaga Kerja dalam Kegiatan Penanaman Modal Sektor Perkebunan di Sumatera Barat

Penanaman modal atau investasi berperan penting dalam pembangunan ekonomi, karena melalui investasi dapat meningkatkan kapasitas ekonomi dan menjaga kesinambungan laju pertumbuhan ekonomi. Laju perekonomian yang baik akan memberikan dampak yang baik pula terhadap tingkat perekonomian masyarakat. Pemerintah telah menerbitkan UndangUndang Nomor 25 Tahun 2007 tentang
Penanaman Modal yang bertujuan untuk mendorong tumbuhnya investasi di Indonesia baik dengan dari dalam negeri maupun dari luar negeri. Adanya peningkatan investasi diharapkan akan memacu pertumbuhan perekonomian nasional.

Disamping itu pemerintah telah menerbitkan Undang-Undang Nomor 32 Tahun 2004 tentang Pemerintahan Daerah. Kebijakan tersebut pada dasarnya bertujuan untuk lebih mendorong pemerintah daerah untuk mengembangkan daerahnya secara maksimal dan efisien, sehingga mampu memberdayakan potensi yang ada pada masing-masing daerah guna mencapai kemandirian perekonomian yang akhirnya dapat meningkatkan kemakmuran masyarakat.

Selanjutnya pemerintah Provinsi Sumatera Barat terbuka bagi investor untuk menanamkan modalnya serta mengambangkan usahanya. Namun untuk dapat meyakinkan investor agar bersedia menanamkan modalnya di Provinsi Barat, diperlukan beberapa usaha antara lain bidangbidang apa saja yang memiliki peluang investasi terbaik dan bagaimana fasilitas pendukungnya.

Memperhatikan ketentuan Pasal 4 Ayat (3) Undang-Undang Nomor 25 Tahun 2007 tentang Penanaman Modal, kebijakan dasar penanaman modal diwujudkan dalam bentuk Rencana Umum Penanaman Modal. 
Peran serta pemerintah provinsi Sumatera Barat dalam meningkatkan dan mengembangkan kegiatan penanaman modal di Sumatera Barat sangat luar biasa, pemerintah daerah memfokuskan perhatiannya untuk kesejahteraan perekonomian daerah Sunatera Barat melalui kegiatan penanaman modal yang bergerak diberbagai sektor salah satunya sektor perkebunan.

\section{PENUTUP}

Dalam Pemerintah Provinsi Sumatera Barat telah mengeluarkan regulasi berupa Peraturan Daerah dan Peraturan Gubernur terkait dengan pelaksanaan kegiatan penanaman modal sektor perkebunan yang berperan dalam penyerapan tenaga kerja di Sumatera Barat. Beberapa regulasi tersebut seperti Peraturan Gubernur Nomor 70 Tahun 2013 tentang Rencana Umum Penanaman Modal Provinsi Sumatera Barat, Peraturan Daerah Provinsi Sumatera Barat Nomor 2 Tahun 2014 tentang Penanaman Modal, Peraturan Daerah Provinsi Sumatera Barat Nomor 16 Tahun 2008 tentang Tanah Ulayat dan Pemanfaatannya diperkuat dengan dikeluarkannya Peraturan Gubernur Sumatera Barat Nomor 21 Tahun 2012 tentang Pedoman dan Tata Cara Pemanfaatan Tanah Ulayat Untuk Penanaman Modal serta perlunya sosialisasi dan penyuluhan mengenai dasar hukum tersebut kepada masyarakat.
Dinas Tenaga Kerja dan Transmigrasi mengoptimalisasikan Balai Latihan Kerja (BLK) dan Lembaga Pelatihan Kerja Swasta (LPKS) dengan menyediakan sarana dan prasarana BLK, instruktur serta Lembaga Pelatihan Kerja (LPK) yang terakreditasi, dalam rangka meningkatkan sumber daya manusia bagi tenaga kerja khususnya yang ada di Sumatera Barat.

\section{DAFTAR PUSTAKA}

\section{Buku}

Charles Himawan, The Foreign Investment Process in Indonesia, Gunung Agung, Singapura, 1980

Erman Rajagukguk, 1985. Indonesianisasi Saham, Rineka Cipta, Jakarta.

G. Kartasaputra, 1985. Manajemen Penanaman Modal Asing, Bina Aksara, Jakarta.

Hendrik Budi Untung, Hukum Investasi, Penerbit Sinar Grafika, Jakarta, 2010

Soerjono Soekanto, Faktor-faktor yang mempengaruhi, penegakan hukum, Raja Grafindo Persada, Jakarta, 1983

\section{Undang - Undang}

Undang Undang No. 6 Tahun 1968 tentang Penanaman Modal Dalam Negeri.

Undang-Undang Nomor 13 Tahun 2003 tentang Ketenagakerjaan.

Undang-Undang Nomor 32 Tahun 2004 tentang Pemerintahan Daerah.

Undang Undang Nomor 25 Tahun 2007 tentang Penanaman Modal. 
Peraturan Presiden Nomor 44 Tahun 2016 tentang Daftar Bidang Usaha yang Tertutup dan Bidang Usaha yang Terbuka dengan Persyaratan di Bidang Penanaman Modal.

\section{Internet}

Http://Www.Sindonews.Com/Read/2012/04/ 13/450/610831/Wirausaha-Ri-MasihJauh-Tertinggal.

Http://m. tribunnews. com > bisnis > industri / 11/12/2017/ industri-perkebunan-jadipenopang-ekonomi-nasional.

Https:/M. suara. com > bisnis > 2017/02/04/ industri-sawit-serap-tenaga-kerja-5,7 juta-orang-di-2016.

Www. BKPM. go.id > ppid, file_upload/ laporan-kinerja-BKPM-2016 